\title{
Longevity of Uromyces transversalis, Causal Agent of Gladiolus Rust, under Various Environmental Conditions
}

\author{
M. R. Bonde, S. E. Nester, and D. G. Luster, USDA-ARS, Fort Detrick, Frederick, MD 21702; and C. L. Palmer, IR-4 Project, Rutgers \\ University, Princeton, NJ 08520
}

Accepted by publication 15 January 2015. Published 6 April 2015.

\section{ABSTRACT}

Bonde, M. R., Nester, S. E., Luster, D. G., and Palmer, C. L. 2015. Longevity of Uromyces transversalis, causal agent of Gladiolus rust, under various environmental conditions. Plant Health Progress doi:10.1094/PHP-RS-14-0036.

To help determine if gladiolus rust may spread to new areas of the United States, we studied effects of different temperature and moisture conditions on longevity of Uromyces transversalis urediniospores. Treatments consisted of gladiolus leaf pieces, with actively sporulating uredinia, placed in mesh bags in a plastic beaker without soil (dry) or plastic bags covered in damp soil (damp). These treatments were either held in a greenhouse at $22-26^{\circ} \mathrm{C}$ (warm) or refrigerator at $4{ }^{\circ} \mathrm{C}$ (cool). After 14 days, $59 \%$ of urediniospores maintained under warm, dry conditions were viable compared to only $1 \%$ under warm damp conditions. After 56 days, viability dropped to $3 \%$ and near $0 \%$, respectively. Under cool conditions, by 91 days germination dropped to $0.7 \%$ and $0 \%$, respectively. To determine the potential for corms or soilless mix from infected plants to harbor inoculum, infected gladiolus plants were maintained in a growth chamber progressively simulating fall and winter. Following foliage senescence, corms from infected plants were removed from the soilless mix, stored 11 months at $4^{\circ} \mathrm{C}$, and planted in noninfested soilless mix in the greenhouse. The pots containing soilless mix in growth chambers, upon removal of corms present on infected plants, were maintained in the chambers until fall and then replanted with healthy corms. No pustules developed on either set of plants, indicating that corms from infected plants had not been infected, urediniospores had not survived in the soilless mix, and urediniospores on or in soil did not perpetuate the disease.

\section{INTRODUCTION}

Uromyces transversalis Thum., causal agent of gladiolus rust, is an obligate rust pathogen that grows and reproduces on members of the family Iridaceae, including species within the genera Gladiolus, Tritonia, Crocosmia, and Watsonia. The pathogen originally was given its name because of its characteristic transverse sori which develop across veins of infected leaves (Fig. 1). The first symptoms are small, yellowish spots that develop into pustules commonly measuring $1 \mathrm{~mm} \times 1$ $\mathrm{cm}$ (Fig. 1B). These pustules, containing large numbers of yellowish-orange urediniospores, coalesce into larger lesions around which teliospore-bearing black telia form (Fig. 1F). Spermagonia and aecia are not produced.

The original name Uredo transversalis Thumen was changed in 1884 to Uromyces transversalis (Thum.) Winter (1884). Nearly 100 years later, the disease appeared in northern Africa and southern Europe (Beilharz et al. 2001). In 1979, gladiolus rust was discovered in Argentina (Shubert et al. 2007) and in 1981 in Brazil (Shubert et al. 2007). The disease was discovered to be present in various states in Mexico from 2004 to 2005 (Rodriguez-Alvarado et al. 2006, SAGARPA-SENASICA 2005) and the United States in Florida (Shubert et al. 2007) and California (Blomquist et al. 2007) in 2006. Since then, the disease appears not to have spread within the United States.

The Animal and Plant Health Inspection Service (APHIS), Plant Pest Quarantine (PPQ) considers gladiolus rust to be a

Corresponding author: M. R. Bonde. Email: morris.bonde@ars.usda.gov

doi:10.1094/PHP-RS-14-0036

C 2015 The American Phytopathological Society serious threat to the U.S. horticulture and floral industries, however not established currently in the country (Rizvi et al. 2007). As a result, APHIS is conducting an aggressive eradication program. Included in this program, beginning in 2007 (Rizvi et al. 2007), gladiolus rust surveys have been conducted in California and Florida where Gladiolus spp. are sold as cut flowers and corms, in addition to areas where hosts for the pathogen are grown in residential yards. In order to increase the likelihood of successful eradication, additional information on effects of environment on longevity of gladiolus rust urediniospores is required. To date, we know of only one environmental study on the disease (Peterson et al. 2009). From that study, in which dry urediniospores were held at specific relative humidities, the pathogen remained viable for a maximum of 79 days. The objective of our study was to determine if urediniospores are able to survive in the greenhouse or field long enough to reinitiate disease.

\section{SURVIVAL OF UREDINIOSPORES IN PUSTULES EMBEDDED IN LEAF PIECES UNDER VARIOUS ENVIRONMENTAL CONDITIONS}

Green gladiolus leaves bearing rust pustules were cut into halfinch sections. Three sections from each individual gladiolus leaf were set aside to determine viability of the urediniospores on that leaf at time zero. An additional 192 pieces were individually placed into $20-\mu \mathrm{m}$ pore size polyester mesh bags. Thirty-two bags were put into a beaker, and four bags placed into each of eight 1quart-size plastic bags containing $300 \mathrm{~g}$ damp soil (Sunshine \#1 Mix, with $250 \mathrm{ml}$ water per $100 \mathrm{~g}$ air dried Mix). These were placed on a greenhouse bench at 22 to $26^{\circ} \mathrm{C}$. Sixty-four bags were put into another beaker, and four bags placed into each of sixteen 

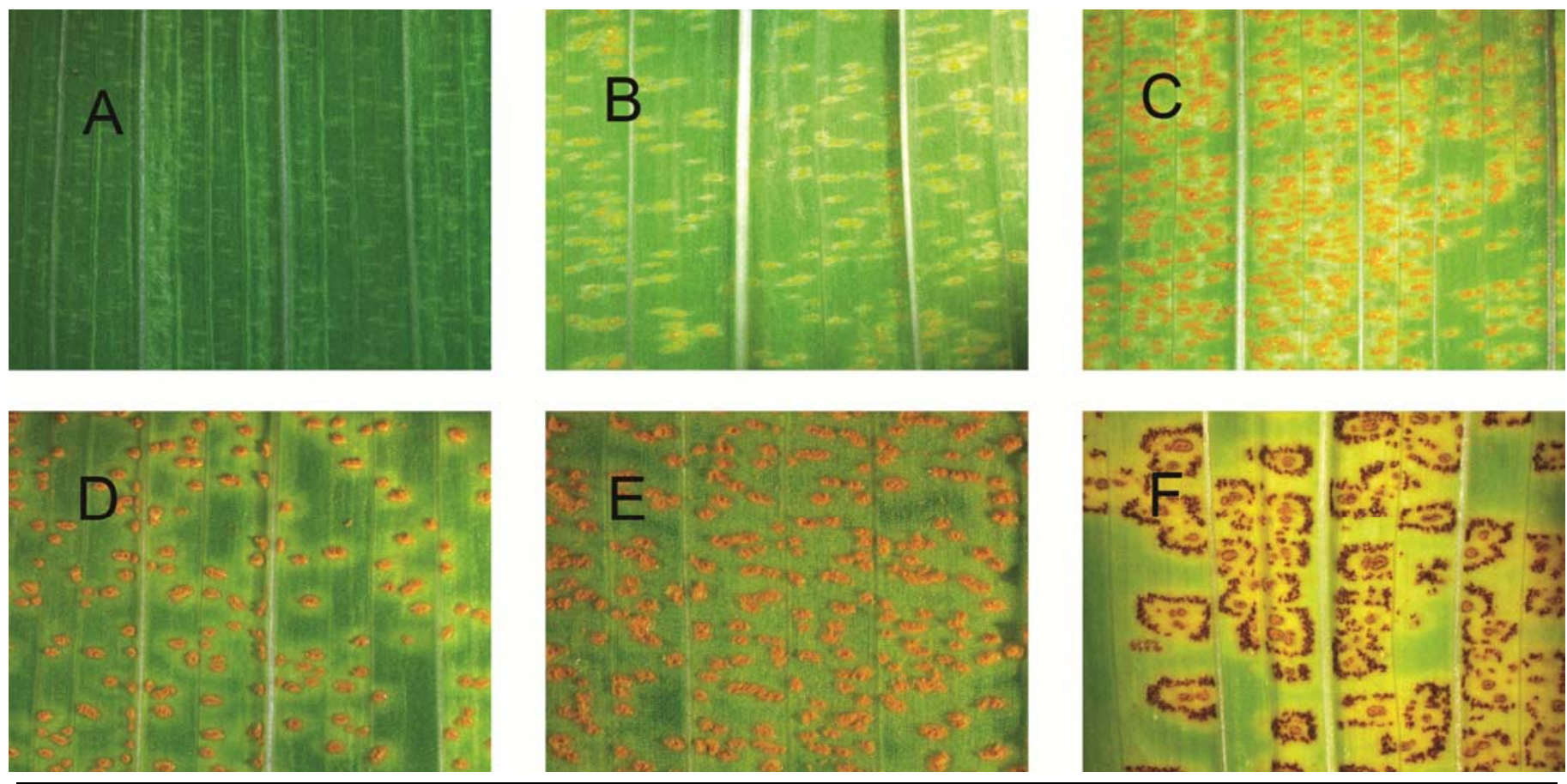

FIGURE 1

Development of gladiolus rust: (A) no infection; (B) early development in leaves; (C) eruption of uredinia; (D and E) maturation of uredinia; and (F) development of telia surrounding uredinia.

1-quart plastic bags containing $300 \mathrm{~g}$ damp soil as above. These samples were placed in a $4^{\circ} \mathrm{C}$ refrigerator to represent the coldest temperatures during winter in Bradenton, Manatee County,

Florida, where the disease has been observed to persist.

At zero time and at weekly intervals thereafter, leaf pieces with pustules were recovered from each environment, placed in 50-ml centrifuge tubes, incubated in an atmosphere at $100 \% \mathrm{RH}$ overnight, covered with $35 \mathrm{ml}$ Tween 20 water ( 1 drop Tween 20 per $100 \mathrm{ml}$ water), and rocked for $30 \mathrm{~min}$ to dislodge spores from pustules. Released urediniospores were plated onto $1 \%$ water agar in petri dishes and incubated overnight at $17^{\circ} \mathrm{C}$. Percent germination was determined by examining 300 spores at $100 \times$ magnification for each of four replicate dishes for each treatment/recovery date. The experiment was conducted three times. The average percent germination was determined for each treatment per experiment. The results for the three experiments were combined, and treatment means and standard error of means calculated based on the three experiments.

After 14 days, 59\% of urediniospores maintained under warm, dry conditions were viable compared to only $1 \%$ maintained under warm damp conditions. After 56 days, viability dropped to $3 \%$ and near $0 \%$, respectively. Under cool conditions, viability exhibited a different pattern. After 14 days, $1 \%$ of urediniospores germinated under cool, dry conditions versus $79 \%$ under cool damp conditions. By 13 weeks, germination dropped to $0.7 \%$ and $0 \%$, respectively. We concluded that under normal field or greenhouse conditions, in which urediniospores must pass through a warm period in the presence of moisture, the pathogen would not survive by means of urediniospores on or in soil for more than a few weeks (Fig. 2).

\section{EVIDENCE FOR LACK OF PATHOGEN TRANSMISSION VIA SYSTEMIC INFECTION}

To determine whether $U$. transversalis systemically infects gladiolus and if infected corms are a source of primary inoculum
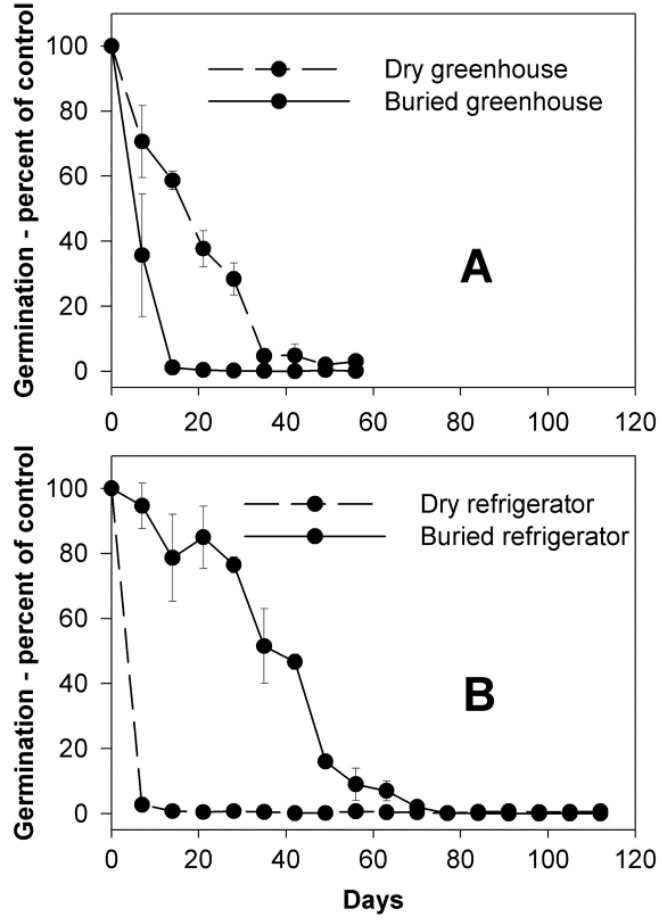

FIGURE 2

Percentage of urediniospores able to germinate on $1.0 \%$ water agar after specific time durations in (A) the greenhouse, buried in soil, or not buried (dry); or in (B) a refrigerator, buried in soil, or not buried (dry). Data are expressed as a proportion of the germination percentages of control urediniospores at time zero. The experiment was conducted three times, with four replicate petri dishes per experiment. Standard errors of the means are indicated. 
in the field, three Gladiolus plants, cv. Border Mix approximately 1 -month in age, were inoculated with a suspension of $U$.

transversalis urediniospores (isolate Manatee Co., FL) and placed overnight in a dew chamber at $18^{\circ} \mathrm{C}$. The following day, the plants were transferred to a greenhouse at $22^{\circ} \mathrm{C}$ to $26^{\circ} \mathrm{C}$. Rust pustules became evident on leaves after approximately 2 weeks. After the plants had died back, the corms and cormlets that had developed from the infected parent plants were removed from the soil, cleaned, and refrigerated at $4^{\circ} \mathrm{C}$ for 2 months. Following refrigeration, the corms were planted in clay pots in the greenhouse. Since dew is required for urediniospore germination and penetration, no dew period was provided. Thus, any disease that developed presumably would have been the result of infected corms, and not urediniospores present in the aerial environment. Five months later, plants that had arisen from the soil were examined for the presence of gladiolus rust pustules. The experiment was repeated exactly as before. No pustules were detected in either experiment, suggesting that $U$. transversalis had not systemically infected corms.

\section{DETERMINATION OF CAPABILITY OF UREDINIOSPORES TO SURVIVE THROUGH SIMULATED WINTER}

A study was conducted to determine if $U$. transversalis urediniospores could survive on the surface of gladiolus corms, or in or on soil, through winter. Eighteen clay pots, each containing two inoculated gladiolus plants, were placed in a growth chamber programmed to simulate the average daily diurnal temperature conditions on November 10 (temperature high $26^{\circ} \mathrm{C}$, temperature low $15^{\circ} \mathrm{C}$ ) in Bradenton, Florida. This location was selected because of its closeness to a location where gladiolus rust was known to have survived through winter. At weekly intervals, the diurnal daily temperature high and low were each stepwise decreased until reaching temperature conditions characteristic for Bradenton at the coldest time of winter. At that point, the diurnal temperature high and temperature low were stepwise increased weekly until reaching temperatures characteristic for Bradenton during spring. The specific temperatures selected were based on average daily temperature records from NOAA for each calendar day for that location from 2000 to 2012.

In spring, corms and newly formed cormlets were removed from the soilless mix, cleaned to remove adhering mix, and placed in a $4^{\circ} \mathrm{C}$ refrigerator to simulate commercial storage. Eleven months later they were planted in soilless mix in pots in the greenhouse. One-half of the pots received weekly dew periods and the other half received no dew periods. After 47 days, a few pustules (one to three) developed on some of the plants receiving weekly dew periods, but not on plants not receiving dew. The numbers of pustules that developed on plants receiving dew were nearly identical to numbers of pustules that developed on sentinel (control) plants that had been placed on the same greenhouse bench and received weekly dew periods.

Following removal of corms from the pots in the growth chamber, the pots were held in the growth chamber through the simulated summer and into November. At that time, two corms of the variety "Border Mix" were planted in the soilless mix in each pot, and pots placed in the greenhouse where they received routine automatic drip irrigation. Plants that developed from the recently planted corms did not become infected by $U$. transversalis.

When the experiment was repeated, nearly identical results were obtained. It was concluded that $U$. transversalis urediniospores were not able to survive on corms from infected plants, nor on or in soilless mix.

\section{CONCLUSIONS AND MANAGEMENT IMPLICATIONS}

Managing gladiolus rust, a regulated disease, involves destruction of symptomatic gladioli plants and those plants surrounding symptomatic plants, careful application of fungicides to prevent new infections in the growers' fields, and a host-free period of 120 days (Rizvi et al. 2007). Our results validate this time frame in that very few urediniospores of $U$. transversalis were able to survive past 60 days under warm conditions and 70 days with cool temperatures, regardless of moisture level. The differential urediniospore viability for dry versus damp conditions, under different temperatures, was somewhat surprising. This perhaps was due to protections inherent with cycling temperatures and relative humidity under greenhouse conditions that enable dry spores to survive until sufficient moisture is present to enable germination. In the refrigerator, desiccation would have been more pronounced with urediniospores that were not buried in the soilless mix. This might have caused the more rapid loss of viability with nonburied urediniospores.

In our plant disease containment greenhouse, it is routine practice with most rust pathogens to subject plants to a single dew period. This minimizes the possibility of unwanted cross contamination. Future research will determine if multiple dew periods might promote infection by $U$. transversalis in soil.

Based on patterns of gladiolus rust outbreaks, the pathway of introduction into the United States may be through imported cut flowers from countries with endemic $U$. transversalis populations even when growers are following guidelines to strip leaves from flower stems. While urediniospores do not possess long viability, it is possible during tropical storms and hurricanes that spores can be blown from Mexico and the Caribbean countries to Florida production areas and still be viable. This disease has reappeared multiple times in Florida even when the growers are adhering to strict eradication protocols including the 120-day host free period, and nearby residential areas do not contain any of the host species.

Even though it is apparent that $U$. transversalis urediniospores cannot survive for long durations in soil under normal greenhouse or field conditions, there are other ways the pathogen might survive. One is that, theoretically, this fungus could survive internally as a systemic infection below the soil surface, such as with Puccinia horiana, causal agent of chrysanthemum white rust, in chrysanthemum (Bonde et al. 2015). However, results from the present study suggest that this does not occur with gladiolus rust.

A second possibility is that the pathogen might survive on gladiolus stems or leaves as teliospores. Several attempts to germinate teliospores of $U$. transversalis were unsuccessful (data not presented), suggesting that special environmental conditions may be required for teliospore germination. Clearly, further studies must be conducted to elucidate the reasons for recurring infections from season to season.

\section{DISCLAIMER}

Mention of trade names or commercial products in this publication is solely for the purpose of providing specific information and does not imply recommendation or endorsement by the U.S. Department of Agriculture. USDA is an equal opportunity provider and employer.

\section{ACKNOWLEDGMENTS}

Funding for this research was partially supported by the USDAAPHIS-CPHST through the FY2011, FY2012, and FY2013 Farm Bills. 


\section{LITERATURE CITED}

Beilharz, V., Parbery, D. G., and Pascoe, I. G. 2001. Gladiolus rust (caused by Uromyces transversalis) in eastern Australia. Australas. Plant Pathol. 30:267-270.

Blomquist, C. L., Thomas, S. L., McKemy, J. M., Nolan, P. A., and LuqueWilliams, M. 2007. First report of Uromyces transversalis, causal agent of gladiolus rust, in San Diego County, California. Plant Dis. 91:1202.

Bonde, M. R., Murphy, C. A., Bauchan, G. R., Luster, D. G., Palmer, C. L., Nester, S. E., Revell, J. M., and Berner, D. K. 2015. Evidence for systemic infection by Puccinia horiana, causal agent of chrysanthemum white rust, in chrysanthemum. Phytopathology 105:91-98.

Peterson, G. L., and Berner, D. K. 2009. Effects of temperature and humidity on the survival of urediniospores of gladiolus rust (Uromyces transversalis). Eur. J. Plant Pathol. 125:509-513.
Rizvi, A. S., Man-Son-Hing, A., Jackson, A. S., Parra, G. R., Schartzburg, K. A., Brown, L. G., Sullivan, M. J., Duffie, L. E., Kosta, K. L., Clark, R., Kastamy, R., and Schbert, T. 2007. Gladiolus rust (Uromyces transversalis): a national management plan for exclusion and eradication. USDA APHIS PPQ, Washington, DC

http://www.aphis.usda.gov/plant_health/plant_pest_info/gladiolus_rust/do wnloads/grust-ntlmgntplan.pdf.

Rodriguez-Alvarado, G., Fernandez-Pavia, S. P., Valenzuela-Vazquez, M., and Loya-Ramirez, J. G. 2006. First report of gladiolus rust caused by Uromyces transversalis in Michoacan, Mexico. Plant Dis. 90:687.

SAGARPA-SENASICA. 2005. Roya del gladiolo Uromuces transversalis. Cartilla de gladiolo. No. 127. Col. Del Carmen, Coyoacan, Mexico.

Shubert, T. S., Leahy, R. M., Davison, D. A., Silagyi, A. J., and Killgore, E. M. 2007. Gladiolus rust caused by Uromyces transversalis makes first nearctic appearance in Florida. Plant Dis. 91:1202.

Winter, G. 1884. Exotische Pilze. Flora (Jena) 67:259-274. 